ارزيابى تانيك اسيد بهعنوان منعقد كننده در كاهش كدورت آب در تصفيه مقدماتى

هستى هاشمى نزاد"، امير تائبى و يويا پايدارى'

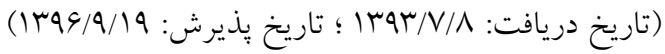

جكيده

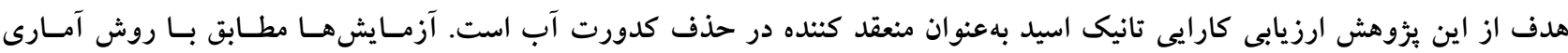

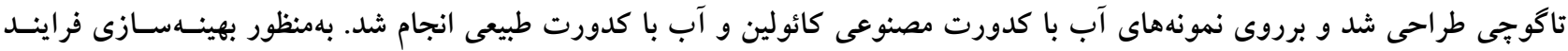

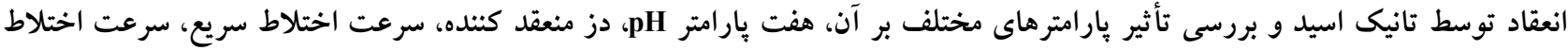

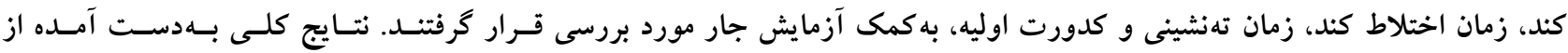

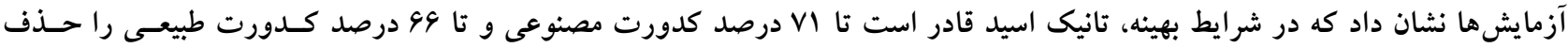

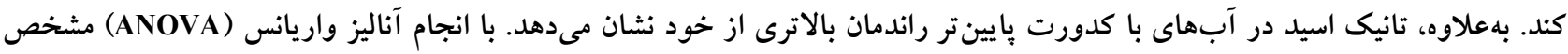

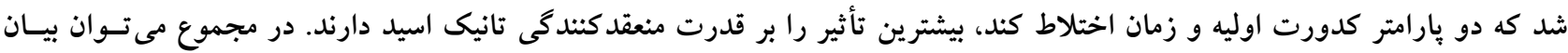

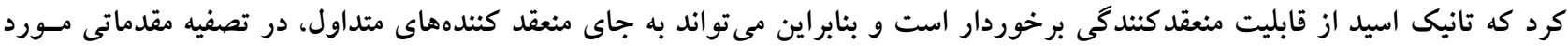
استفاده قرار كيرد.

وازههاى كليدى: بيوجار، فلزات سنغين، جذب زيستى، آلودگى آب و خاك 


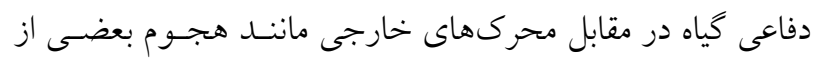

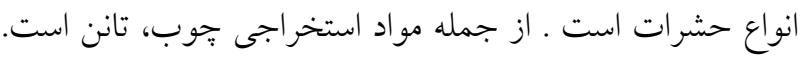

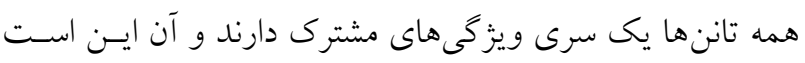

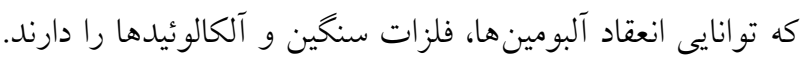

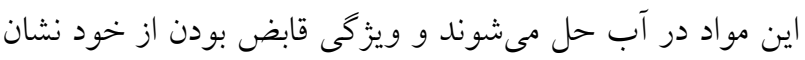

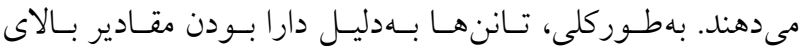

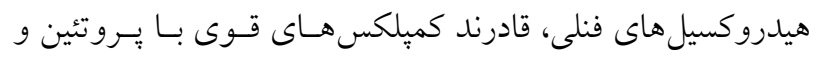

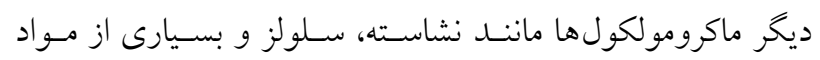

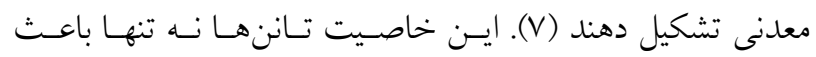

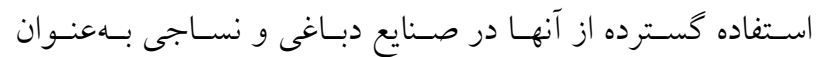
تثنيت كننده شده است بلكه باعث شده تا كـاريى آنها در تصـفيه

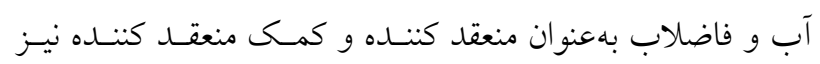

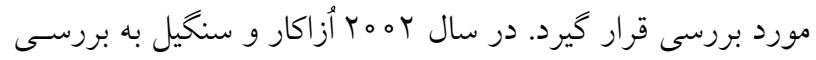

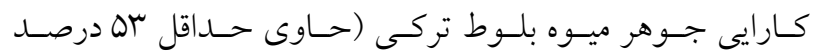

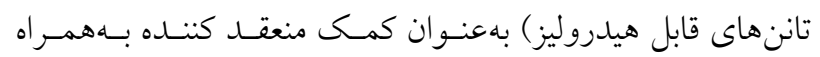

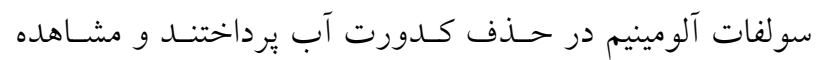
كردند كه دز يك ميلى گرم در ليتر از اين عصاره مىتواند بهطور

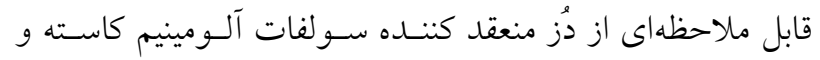

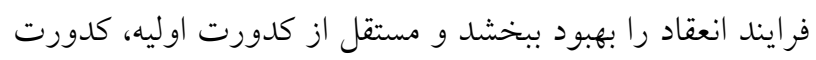

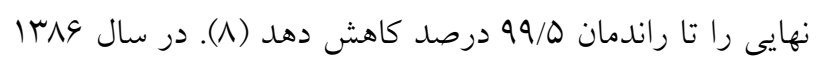

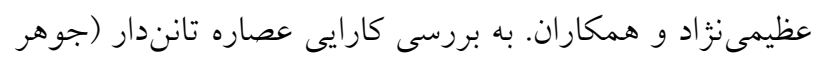

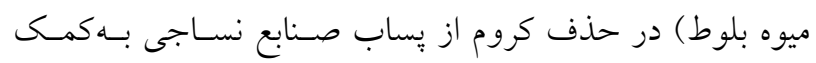

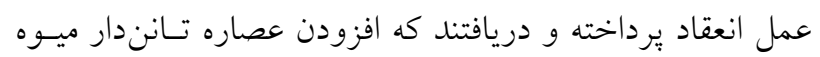

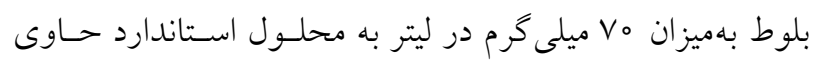

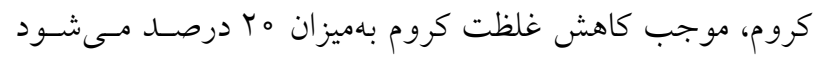

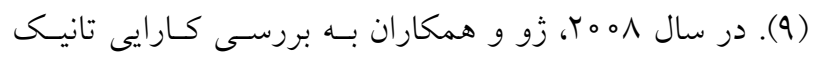
اسيد بهعنوان كمك منعقد كننده بههمراه كلروفريـى در تصـفيه

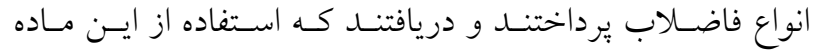

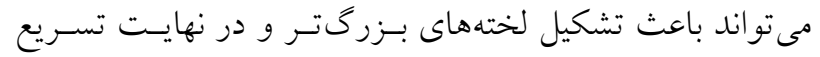

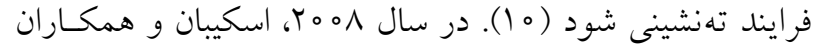

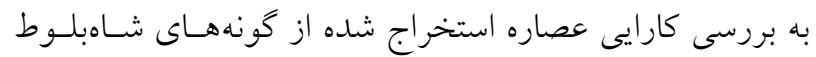

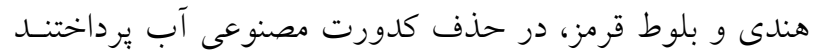

كاهش كدورت همـواره يكسى از اهــاف اصـلى و برهزينسه در

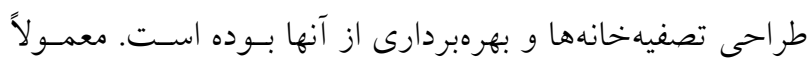

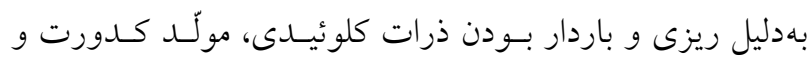

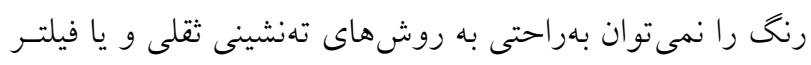

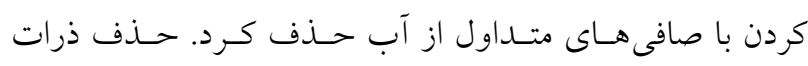

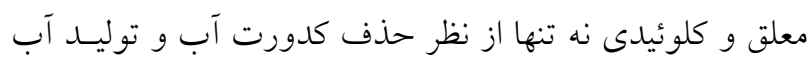

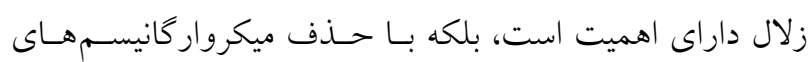

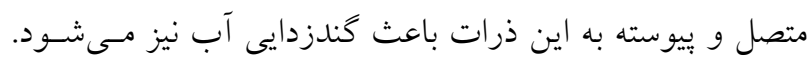

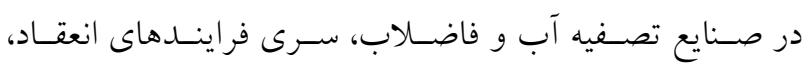

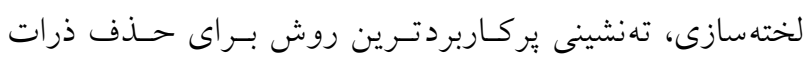

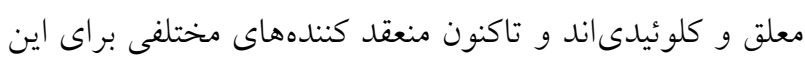

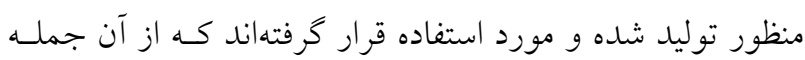
مى توان به منعقد كنندههاى معــنى نظير كلــروفريـك (

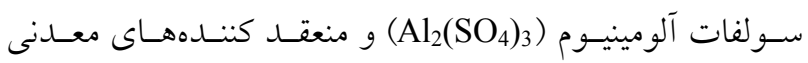
يليمرى مانند يلى آلومينيوم كلر ايد (

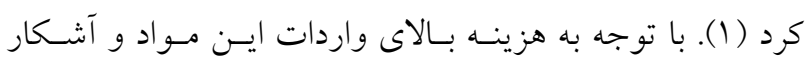

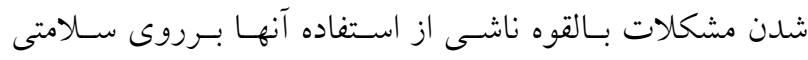

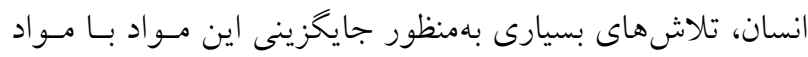

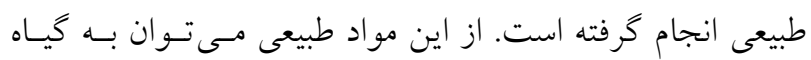

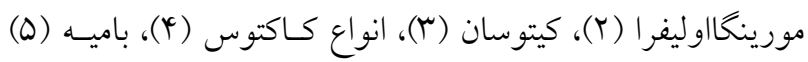

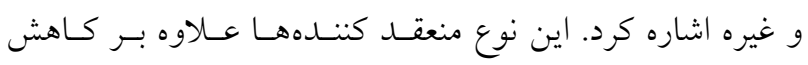

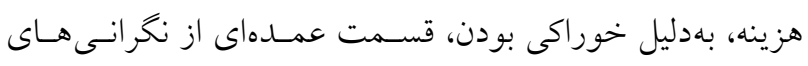

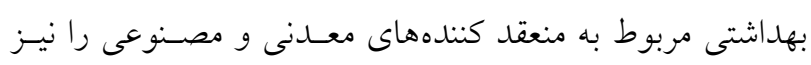
برطرف مى كنند.

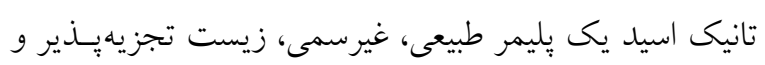

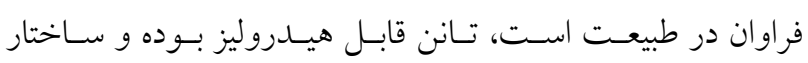

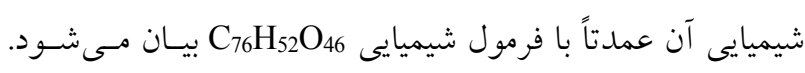

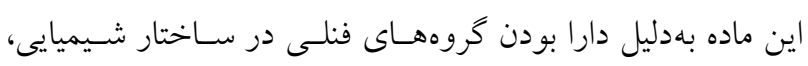

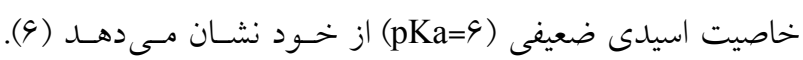

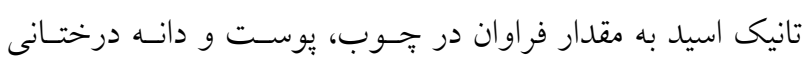

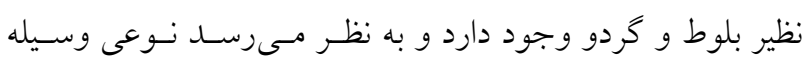


جدول ا. برخى ازخصوصيات فيزيكى وشيميايى آب رودخانه زايندهرود

\begin{tabular}{|c|c|c|c|c|c|c|c|c|}
\hline كدورت & $\begin{array}{c}\text { قليائيت كل } \\
\text { (mg/L) }\end{array}$ & $\begin{array}{l}\text { سختى كل } \\
\text { (mg/L) }\end{array}$ & كل ذرات معلق & كل ذرات محلول & شورى & $\begin{array}{c}\text { هدايت الكتريكى } \\
(\mu \mathrm{S} / \mathrm{cm})\end{array}$ & $\mathrm{pH}$ & مر حله \\
\hline 1,1 & 10,01 & Ylo & M⿻ & $r \& V, r$ & $0, \mu$ & $\Delta \Delta r$ & 1,1 & اول \\
\hline$Y, Y$ & $11, r$ & TYO & $\mu \mu_{0}$ & $r q 0,1$ & $0, r$ & 010 & 1,1 & دوم \\
\hline
\end{tabular}

افـزايش كـدورت بـهـ حجــم مـورد نظـر از نمونسه آب مقطـر، بهصورت مرحلهاى اضافه شد تـا كـدورتهــاى مـورد نظـر در نمونهها بهدست آيد. آب با كدورت طبيعى از رودخانه زايندهرود و در دو مرحله برداشت شد. كستره خصوصيات فيزيكى و شيميايى نمونههـاى

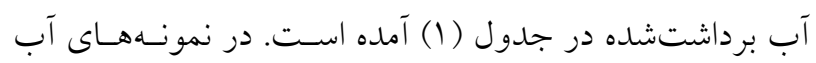
طبيعى رودخانـه، بـهمنظـور افـزايش دامنـه تغييـرات كـدورت نمونههاى آب، از گل و لاى بستر رودخانه استفاده شد. بـه ايسن

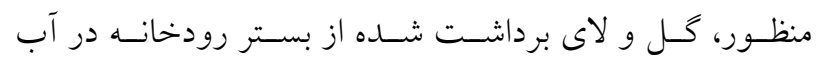
رودخانه بهمدت يكى ساعت مخلوط و سيس بهمنظور تهنشـينى ذرات درشت تر آب كل آلود، نمونهها بهمدت ه ا دقيقه به حالت سكون رها مىشدند. در هر آزمايش، آب رويى مخلوط حاصل، جهت افزايش و رساندن كدورت نمونه به كـدورت مـورد نظـر بهصورت مرحلهاى به نمونه آب طبيعى اضافه شد.

\section{طر احى و انجام آزمايشها}

آزمايشها به كمك دستخاه جار تست انجام شد. از روش آمارى تاگوجى براى تعيين شرايط بهينه همجنين تعيين ميـزان حـداكثر رانـدمان حــفف، در طـرح آزمـايشهــا اسـتفاده شـــ. در روش

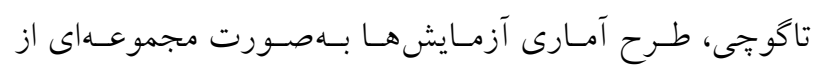

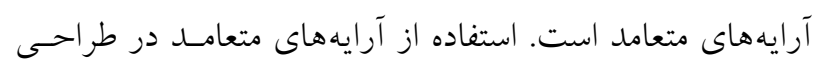
آزمايشها، تعداد آزمايشهاى مورد نياز براى بررسى را بهميـزان

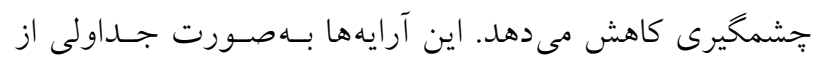
بيش طراحى شدهاند كه با توجــه بـه تعـداد يارامترهـاى مـورد

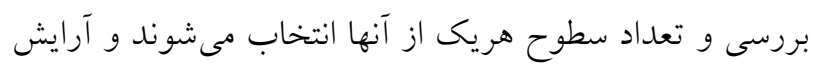

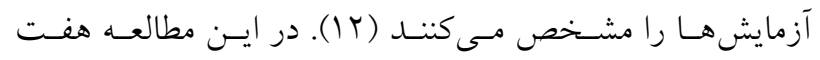

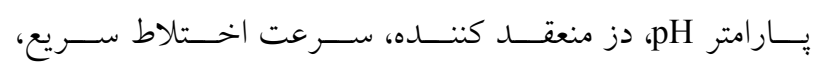

و دريافتند كه اين دو ماده بهترتيب كارايى برابر مبرو V درصــ در حذف ذرات كلوئيدى از خود نشان مىدهند (11). هـدف از اين يزؤوهش، ارزيابى كارايى تانيك اسيد بهعنـوان منعقــ كنــده در حذف كدورت آب است.

\section{مواد و روشها} تهيه محلول تانيك اسيد در اين مطالعه از تانيك اسيد توليـدى شـركت مـرك بـا درجـهـ خلوص بالاى 91 درصد استفاده شد. براى تهيه محلـول تانيـى

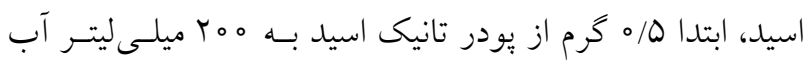

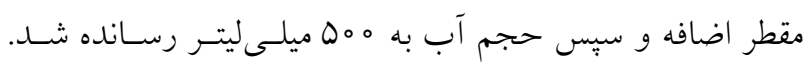
يس از آن، مخلوط حاصل بهمدت • دور در دقيقه توسط همزن مغناطيسى مخلـوط شــ، ســس از محلول رويى بهعنوان محلول تانيك اسيد در آزمايشها اسـتفاده مى شد.

تهيه نمونه در اين مطالعه، از نمونـه آب بـا كـدورت مصـنوعى بـهـمنظـور بررسى كارايى تانيك اسيد بهعنوان منعقد كننده و ايجـاد امكـان

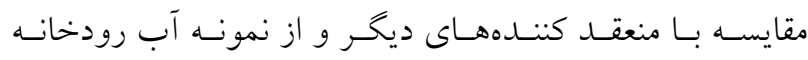
زايندهرود با كدورت طبيعى بهمنظور يتانسيل سـنجى اسـتفاده از تانيك اسيد در تصفيه آب شهرى استفاده شد.

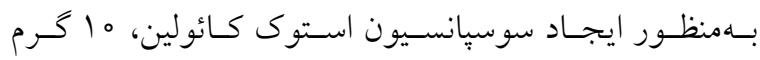
كائولين در يـك ليتـر آب مقطر ريختسه و مخلـوط حاصـل بـا سرعت همب دور بر دقيقه و بهمدت يكى ساعت به هم زده شـد. يس از ب M ساعت مايع رويى بهعنوان استوك مورد استفاده قـرار كرفت. به اين ترتيب كـه سوسيانسـيون اسـتوك حاصـل، بـراى 
جدول r. بֶار امترها و سطوح آنها در اين مطالعه

\begin{tabular}{|c|c|c|c|c|c|c|c|}
\hline كدورت اوليه & زمان تهنشينى & زمان اختلاط كند & سرعت اختلاط كند & سرعت اختلاط سريع & $\begin{array}{c}\text { دز منعقد كننده } \\
\text { (mg/L) }\end{array}$ & $\mathrm{pH}$ & سطح \\
\hline ه广> كدورت & 0 & 10 & $\mu_{0}$ & 100 & 0 & q & سطح 1 \\
\hline $9 \circ \pm 10$ & 10 & ro & Q。 & $10 \circ$ & 10 & 9 & سطح r \\
\hline$\mu_{\circ} \circ \pm$ & r。 & r。 & V。 & roo & 10 & $\wedge$ & سطح r \\
\hline$V Q \circ \pm \Delta \circ$ & 40 & $\varphi_{0}$ & 90 & TQ० & ro & 10 & سطح \\
\hline
\end{tabular}

متر استفاده شد. براى برداشت نمونه از هر آزمايش، از عمـق

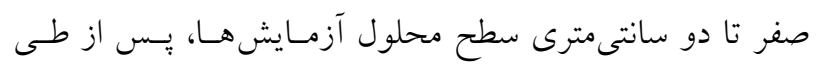

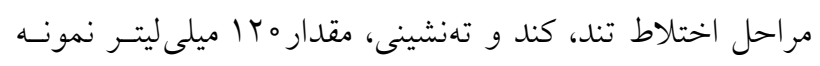

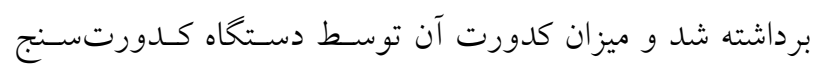
قرائت شد. راندمان حذف كدورت در اين مرحله بـا استفاده از رابطه (1) تعيين شد.

$$
\mathrm{R}=\frac{\mathrm{T}_{\mathrm{B}}-\mathrm{T}_{\mathrm{s}}}{\mathrm{T}_{\mathrm{B}}} \times 100
$$

R و Ts TB Ts Tدتيب كدورت باقيمانده در شاهد و در نمونسه و R راندمان يا كارايى است. هرجه، R بزرگتر باشد مطلوبتر است، جر اكه نشاندهنده راندمان بالاتر حذف كدورت است. شرايط بهينه و حداكثر راندمان حذف كدورت براى هـر نمونسه آب، توسط نرمافزار Qualitek-Y ييشبينى شد. آزمايش هـاى تأيسـد كننده در شرايط بهينه يِيشبينى شده انجـام شـد و رانـدمان آنهـا بـا راندمان بيشبينى شده توسط نرمافزار مقايسه شد. همجنين بهمنظـور

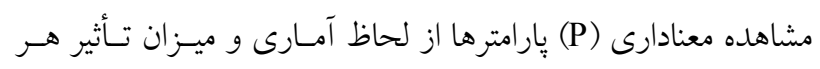
يك در فرايند بررسى شد، آناليز واريانس (ANOVA) برروى نتايج حاصل بنكمك اين نرمافزار انجام شد.

\section{نتايج و بحث}

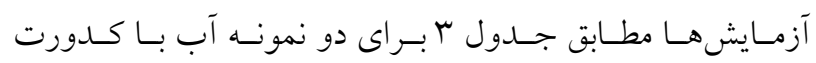
مصنوعى و آب با كدورت طبيعى انجام شد. شـكل هـاى ( ا و r) بهترتيب ميانخين درصد حذف كـدورت در آزمـايشهـاى انجـام

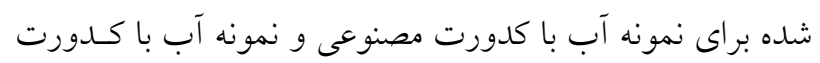
طبيعى را نشان مى دهند. برخى از آزمايشها راندمان منفى داشـتند كه در اين مطالعه راندمان آنها صفر در نظر كرفته شد.
سرعت اخـتلاط كنــ، زمـان اخـتلاط كنـد، زمـان تـهنشـينى و كدورت اوليه مورد بررسى قرار گرفته و بــراى هـر يـك جهــار سطح انتخاب شد. يارامترها و سـطوح در نظـر كرفتـه شـده در طراحى آزمايشها در جدول (Y) نمايش داده شدهاند. محسدوده

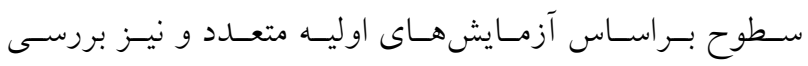
محدودههاى در نظر گرفته شده در منابع مختلف، انتخاب شدند (1، 9، ه ا و 1ا). لازم به ذكر اسـت كـه زمـان اخـتلاط سـريع به آعنوان يـك يـارامتر مسـتقل در نظـر كرفتـه نشـــ و در تمـام آزمايشها ثابت و برابر يك دقيقه فرض شد. بهمنظور طراحسى آزمـايشهـا و تجزيسه و تحليـل نتـايج، از

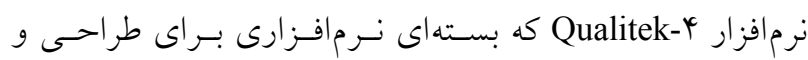
تحليل آزمايشها منطبق بر روش تاكوجى اسـت، اسـتفاده شــد. حاصل طراحى آزمايشها به كمى روش تاكوجى آرايه

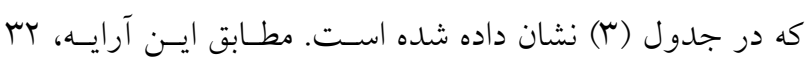
آزمايش براى هر يك از دو نمونه آب بـا كـدورت مصسنوعى و آب با كدورت طبيعى انجام شد. اعداد نوشته شــده در زيــر هـر

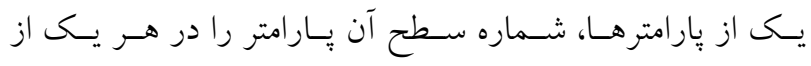
آزمايش ها مشخص مى كنند. بهمنظور حسداقل كـردن اتــر منـابع خطا، ترتيب انجام آزمايشها بهصورت تصادفى انتخاب شد.

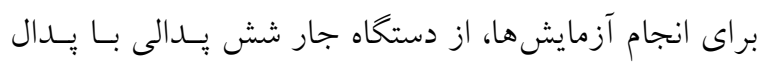

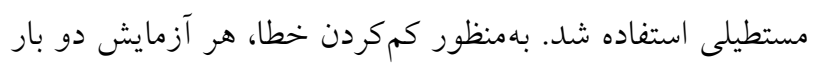
تكرار و در هر بار، يك نمونه بدون اضـافه كـردن تانيـى اسـيد

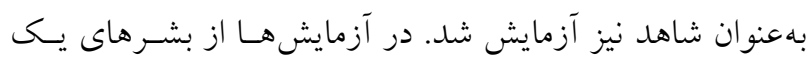

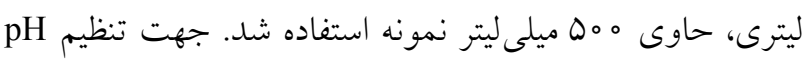

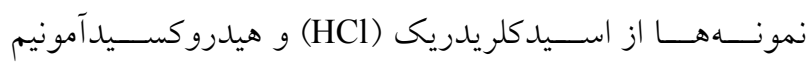
بـا غلظـتهــاى / (NH $\left(\mathrm{NH}_{*}(\mathrm{OH})\right)$ 
جدول r. آرايه متعامد L32 تاكوجى

\begin{tabular}{|c|c|c|c|c|c|c|c|}
\hline سرعت اختلاط تند & سرعت اختلاط كند & زمان اختلاط كند & زمان تهنشينى & كدورت اوليه & دز منعقد كنده & $\mathrm{pH}$ & آزمايش \\
\hline 1 & 1 & 1 & 1 & 1 & 1 & 1 & 1 \\
\hline r & r & r & r & r & r & 1 & r \\
\hline r & r & r & r & r & r & 1 & r \\
\hline r & $r$ & r & r & r & $r$ & 1 & 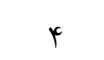 \\
\hline r & r & r & r & 1 & 1 & r & 0 \\
\hline$r$ & $r$ & 1 & 1 & r & r & r & 9 \\
\hline 1 & 1 & $r$ & $r$ & r & r & r & v \\
\hline r & r & r & r & c & $r$ & r & $\wedge$ \\
\hline r & 1 & r & r & r & 1 & r & 9 \\
\hline 1 & r & r & $r$ & 1 & r & r & 10 \\
\hline r & r & r & 1 & r & r & r & 11 \\
\hline r & r & 1 & r & r & $r$ & r & ir \\
\hline r & r & r & $r$ & r & 1 & r & ir \\
\hline r & r & $r$ & r & 1 & r & r & 14 \\
\hline r & 1 & 1 & r & q & $r$ & $r$ & 10 \\
\hline 1 & $r$ & r & 1 & $r$ & $r$ & $r$ & 19 \\
\hline$r$ & $r$ & $r$ & 1 & r & 1 & 1 & IV \\
\hline 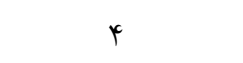 & 1 & $r$ & r & r & $r$ & 1 & 11 \\
\hline$r$ & k & r & $r$ & r & $r$ & 1 & 19 \\
\hline$r$ & $r$ & 1 & q & 1 & r & 1 & ro \\
\hline 1 & r & $r$ & r & 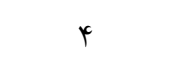 & 1 & r & rl \\
\hline r & $r$ & $r$ & 1 & r & r & r & rr \\
\hline$r$ & r & 1 & k & r & $r$ & r & rr \\
\hline$r$ & 1 & $r$ & $r$ & 1 & $r$ & r & YY \\
\hline r & r & 1 & $r$ & $r$ & 1 & $r$ & ro \\
\hline$r$ & 1 & $r$ & $r$ & $r$ & $r$ & $r$ & rq \\
\hline$r$ & r & $r$ & 1 & 1 & $r$ & $r$ & TV \\
\hline 1 & $r$ & $r$ & $r$ & $r$ & r & $r$ & ru \\
\hline$r$ & r & $r$ & r & $r$ & 1 & $r$ & rq \\
\hline 1 & $r$ & 1 & $r$ & r & $r$ & $r$ & $r_{0}$ \\
\hline r & $r$ & $r$ & $r$ & 1 & $r$ & $r$ & $r_{1}$ \\
\hline$r$ & 1 & $\mu$ & 1 & r & $r$ & r & rr \\
\hline
\end{tabular}

شده است. توسط نرم|فزار Qualitek-4، آناليز واريانس بـر بورى نتـايج

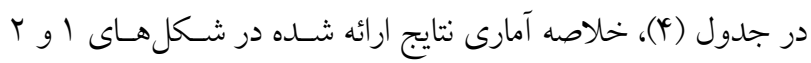

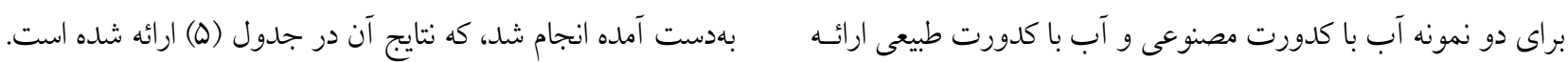




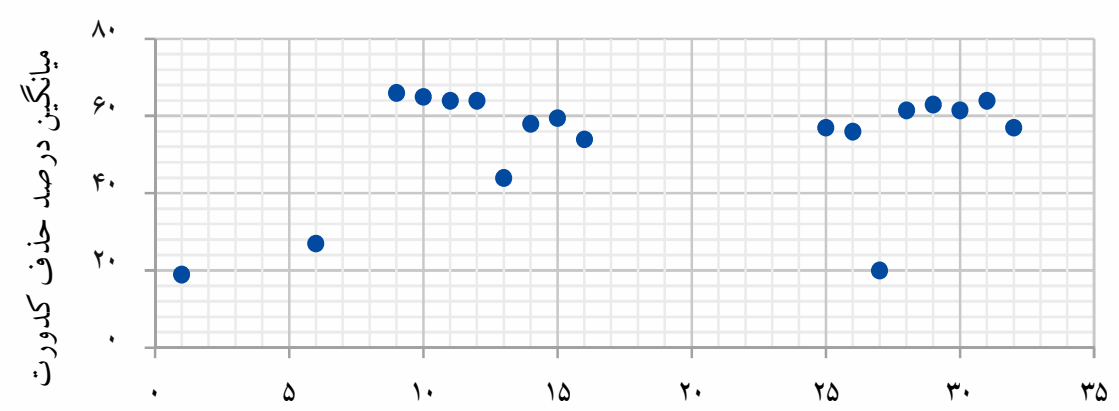

شماره آزمايش

شكل ا. ميانخين درصد حذف كدورت در آب مصنوعى در طرح آزمايش تاكوجى

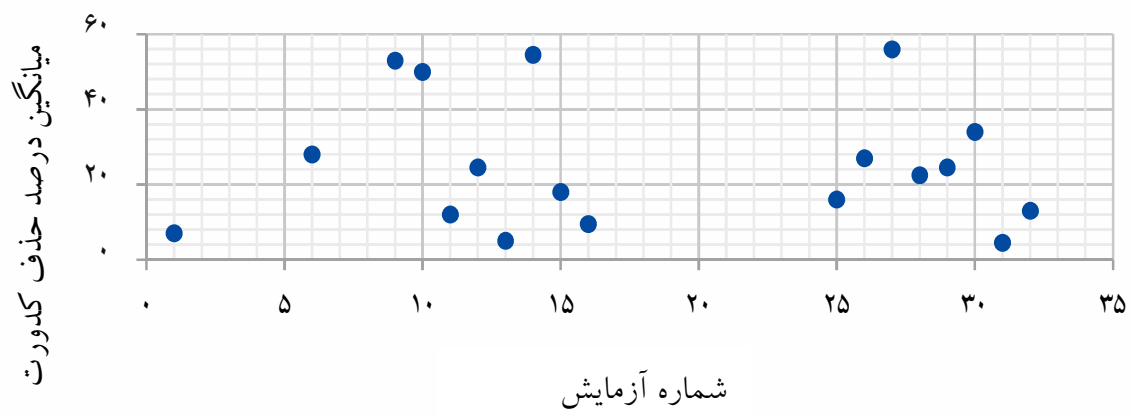

شكل r. ميانگين درصد حذف كدورت در نمونه آب طبيعى در طرح آزمايش تاگوجى

جدول ץ. خلاصه آمارى نتايج بهدست آمده

\begin{tabular}{|c|c|c|}
\hline آب با كدورت طبيعى & آب با كدورت مصنوعى & شاخص آمارى \\
\hline $14, T_{9}$ & $r_{0,01}$ & ميانگين \\
\hline 9,00 & ס סוז & 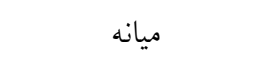 \\
\hline 00,90 & 90,99 & ماكزيمم درصد حذف \\
\hline $\mid 1,1 \mu$ & $r q, T^{*}$ & انحر اف معيار \\
\hline
\end{tabular}

آناليز واريانس مشخص كرد كه عامل دز منعقد كننده بـراى هـر است. يارامترهاى مـؤثر و سـطوح بهينـهـ يـيشبينى شـده توسـط

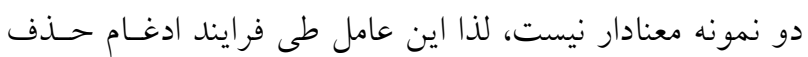
نرمافزار در جدول (9) نشـان داده شـدهاسـت. شـرايط بهينـه و

حداكثر راندمان حذف توسط تانيـك اسـيد بـهـمـك نـرمافـزار

كدورت اوليه و زمان اختلاط كند بهترتيب با س/K درصد و Qualitek-Y

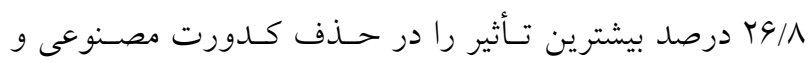
در شرايط بهينه توسط نرمافزار، آزمـايشهـاى تأييـد كنتـده

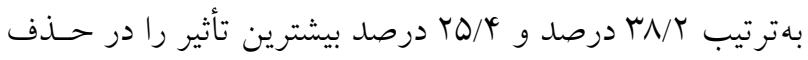
كدورت طبيعى توسط تانيك اسيد در جدول ه نشان داده شـده براى هر نمونه اجراو وراندمان آن با رانـدمان حسـف يـيشبينى 


\begin{tabular}{|c|c|c|c|c|c|c|}
\hline \multicolumn{6}{|c|}{ نمونه } & \multirow[t]{2}{*}{ يارامتر } \\
\hline درصد (P) & نسبت F & واريانس (V) & درصد (P) & نسبت F & واريانس (V) & \\
\hline$V / D 1$ & $\Delta / T_{1}$ & ITrV & $V / 9 r$ & $\Delta / r V$ & $\mid 10 / V 1$ & $\mathrm{pH}$ \\
\hline \multicolumn{3}{|c|}{ Pooled } & \multicolumn{3}{|c|}{ Pooled } & دز منعقد \\
\hline rN/IV & $Y Y / Y Q$ & $\Delta V Y / \Lambda I$ & $\mathrm{MV} / \mathrm{TS}$ & $T Y / D Y$ & YAT/Ar & كدورت اوليه \\
\hline $0 / 01$ & $4 / 0 q$ & $104 / V 1$ & $\Delta / \wedge \Delta$ & $Y / T Y$ & $91 / 00$ & زمان تهنشينى \\
\hline$r \Delta / r \Lambda$ & $10 / K 9$ & $\mu q \circ / 04$ & TG/VG & $10 / V 0$ & & زمان كند \\
\hline$r / \wedge 9$ & T/9T & $9 \mathrm{~V} / 19$ & $r / l 。$ & YNI & $\Delta \Lambda / \mu \Lambda$ & سرعت كند \\
\hline$r / Y^{r}$ & $T / Y I$ & $\Delta G / \Gamma \wedge$ & $r / 9 \mu$ & $T / F Q$ & $\Delta T / V V$ & سرعت تند \\
\hline $\mid \Lambda / \mu \wedge$ & - & $r \Delta / \Delta \omega$ & $19 / 44$ & - & TI/OT & ديخر / خطا \\
\hline 100 & - & - & 100 & - & - & كل \\
\hline
\end{tabular}

جدول 9. سطوح بهينه يارامترها

\begin{tabular}{|c|c|c|c|c|}
\hline \multicolumn{2}{|c|}{ نمونه آب با كدورت طبيعى } & \multicolumn{2}{|c|}{ نمونه آب با كدورت مصنوعى } & \multirow[t]{2}{*}{ 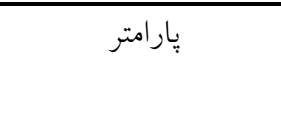 } \\
\hline مقدار سطح & سطح & مقدار سطح & سطح & \\
\hline$\wedge$ & $r$ & 10 & $r$ & $\mathrm{pH}$ \\
\hline 10 & r & 10 & r & دز منعقد كننده (mg/L) \\
\hline rQ & 1 & TQ & 1 & كدورت اوليه (NTU) \\
\hline 0 & 1 & 0 & 1 & زمان تهنشينى (min) \\
\hline 10 & 1 & 10 & 1 & زمان كند (min) \\
\hline 90 & r & V。 & r & سرعت كند (rpm) \\
\hline 100 & 1 & 100 & r & سرعت تند (rpm) \\
\hline
\end{tabular}

طبيعى مى توان دست يافت. اين نتايج منطبق بر نتايج حاصـل از

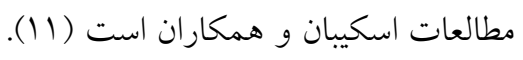
با دقت در جدول (9) موارد زير را مىتوان مطرح كرد:

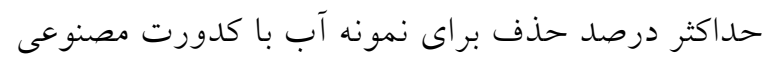

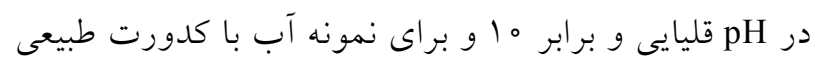

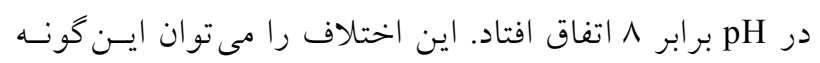

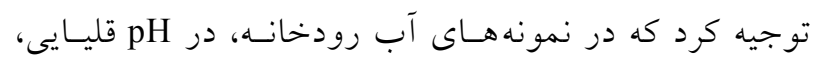

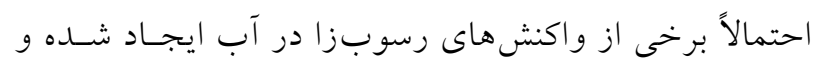

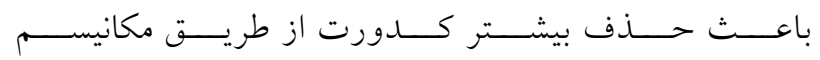
لختسه جـاروبكنتــه (Sweeping flock) در نمونسه شـاهد
شده، توسط نرمافزار Qualitek- مقايسه شد. نتسايج بـيشبينى

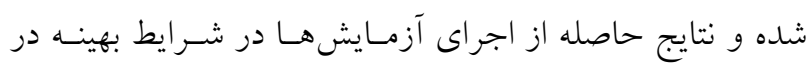
جدول (V) نشان داده شده است.

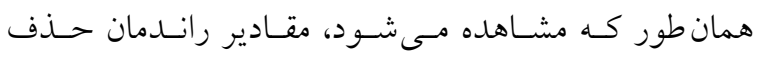

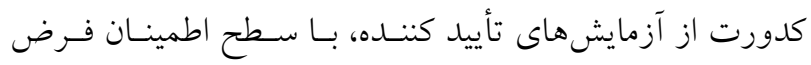

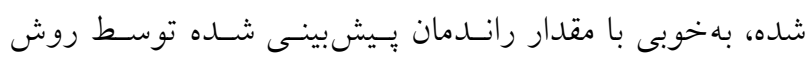

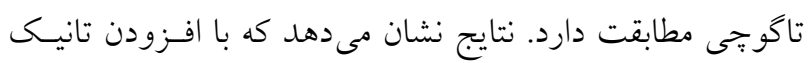

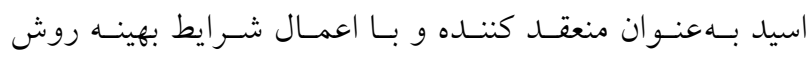

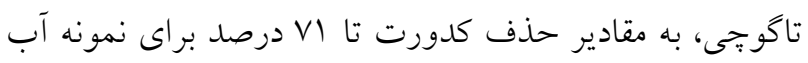

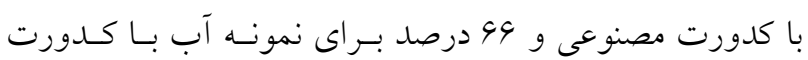


جدول V. نتايج بيشبينى شده توسط نرمافزار و نتايج حاصل از اجراى آزمايشها در شرايط بهينه

\begin{tabular}{|c|c|c|c|c|c|c|c|}
\hline \multicolumn{4}{|c|}{ نمونه آب با كدورت طبيعى } & \multicolumn{4}{|c|}{ نمونه آب با كدورت مصنوعى } \\
\hline \multicolumn{3}{|c|}{ نتايج ييشبينىشده در شرايط بهينه } & \multirow{2}{*}{ 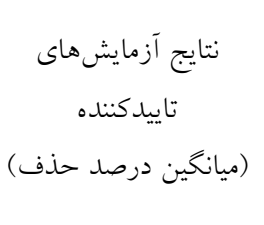 } & \multicolumn{3}{|c|}{ نتايج ييشبينىشده در شرايط بهينه } & \multirow{2}{*}{$\begin{array}{c}\text { نتايج آزمايشهاى } \\
\text { تاييدكننده } \\
\text { (ميانخين درصد حذف) }\end{array}$} \\
\hline بازه اطمينان & سطح اطمينان & ميانخين & & بازه اطمينان & اطمينان & حزيد & \\
\hline $\pm V / r \Delta$ & 90 90 & $\Delta Q / Y 1$ & $D G / K G$ & $\pm Q / \uparrow Q$ & 909 درصد & $99 / 19$ & $q K / 41$ \\
\hline
\end{tabular}

بوده و سريعاً تهنشين مسىشـوند. ايسن نتيجـهـ كـاملاً منطبـق بـا مطالعات زو و همكاران است (1).

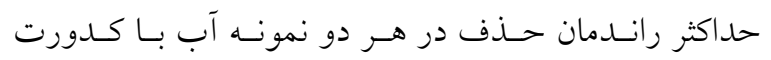
مصنوعى و آب با كدورت طبيعى در سـطح اول يـارامتر زمـان اختلاط كند اتفاق افتاده است. به نظر مىرسد لختههـاى تانيـى اسيد سست بوده و با ادامه اختلاط، لختههاى ايجاد شده از بـين رفته و ذرات كلوئيدى مجدداً در محيط يراكنده مىشوند.

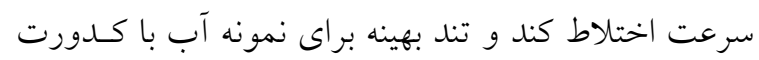

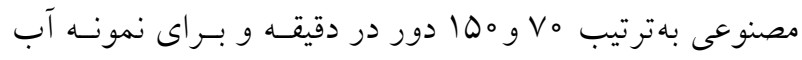
با كدورت طبيعى، ه9 و ه ما دور در دقيقه بهدست آمده است.

\section{نتيجه كيرى}

در ايسـن مطالعـه كـارايى تانيـك اسـيد در حسـذف كـدورت از نمونههاى آب با كدورت مصنوعى و طبيعى مورد مطالعسه قـرار كرفته است و موارد زير را مىتوان نتيجه كيرى كرد:

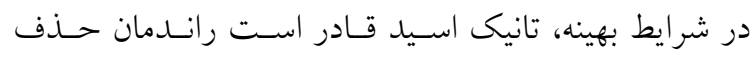
كدورت مصنوعى و طبيعى را بهترتيب VI لدرصد و 94 درصـد افزايش دهد. آناليز واريانس نشان داد براى هر دو نمونه آب بـا كـدورت مصنوعى و آب با كدورت طبيعى، بهجز بارامتر دز منعقدكننـده، تمام بار امترهاى مورد مطالعه اثر معنادار بر راندمان حذف ذرات كلوئيدى دارند. حداكثر رانـدمان حـذف در هـر دو نمونسهـ آب بـا كـدورت مصنوعى و آب با كدورت طبيعى در سـطح اول يـارامتر زمـان تهنشينى اتفاق مى افتلد؛ اين مسـئله نشـان مـى دهـــ كـه احتمـالاً
مشاهده شده است. لذا، عدد راندمان حاصله براى نمونه آب بـا كدورت طبيعى در pH قليايى از رابطه ( 1) كو جـتر مىشود.

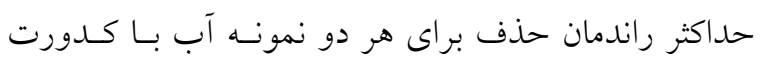
مصنوعى و آب با كدورت طبيعى در دز ه ا ميلى كـرم در ليتـر اتفاق افتاده است. از طرف ديخر در جدول (ه) مشاهده شد كـه يارامتر دز منعقد كننده در هر دو نمونه آب معنادار نبوده است و حذف شده است. معرفى سطح بهينه با توجه به معنـادار نبـودن پار امتر، مى توان با توجه به نحوه طراحى نرمافـزار، آن را ياسـخ داد. طراحى نرمافزار Qualitek-4 به كونهاى است كـه مستقل از معنادارى يكى عامل، سطحى را بهعنـوان سـطح بهينـه آن عامـل معرفى مىكند. اما معنادار نبودن بارامتر دز منعقد كننده مىتواند مربوط به انتخاب نامناسب سـطوح اوليـه دز باشــ. بـه عبـارت ديخر احتمالاً دزهاى منعقد كننده براى نمونه تانيك اسيد بسـيار نزديك بههم انتخاب شدهاند و لذا در اين بازه اختلاف معنادارى از خود نشان ندادهاند. حداكثر رانـدمان حـذف در هـر دو نمونـهـ آب بـا كـدورت مصنوعى و آب با كدورت طبيعى در سطح اول بِارامتر كـدورت اتفاق افتاده است. اين مسئله با توجه به اينكه سطح كدورت آب

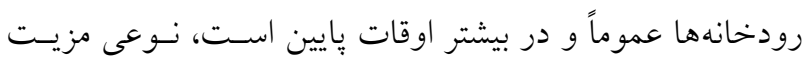

$$
\text { محسوب مى مود. }
$$

حداكثر رانـدمان حـذف در هـر دو نمونـهـ آب بـا كـدورت مصنوعى و آب با كدورت طبيعى در سـطح اول يـارامتر زمـان تهنشينى اتفاق افتاده است. بــهبـارت ديخـــ، بـا افـزايش زمــان تهنشينى، از راندمان حذف كدورت كاسته شده است. اين مسئله

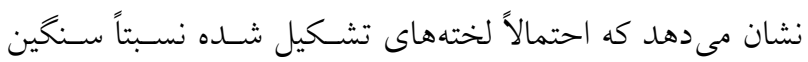




$$
\begin{aligned}
& \text { لختههاى تشكيل شــه نسـبتاً سـنيخين بـوده و سـريعاً تـهنشـين رودخانهها عموماً و در بيشـتر اوقـات يـايين اسـت، نـوعى مزيـت } \\
& \text { مى شونل. }
\end{aligned}
$$

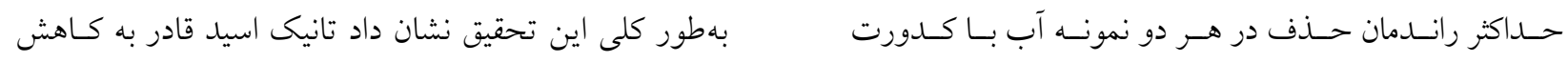

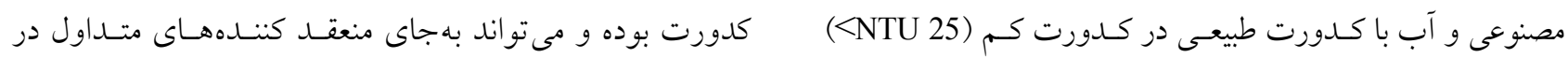

$$
\begin{aligned}
& \text { اتفاق مى افتل كه اين مسئله با توجـه بـه اينكـه سـطح كـدورت آب تصفيه مقدماتى آب استفاده شود. }
\end{aligned}
$$

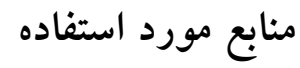

1. Dasgupta, J., J. Sikder, S. Chakraborty, S. Curcio and E. Drioli. 2015. Remediation of textile effluents by membrane based treatment techniques: A state of the art review. Journal of Environmental Management 147(1): 55-72.

2. Beltrán-Heredia, J., Sánchez-Martín, J., Muñoz-Serrano, A. and Peres, J.A. 2012. Towards overcoming TOC increase in wastewater treated with Moringa oleifera seed extract. Chemical Engineering Journal 188(15): 40-46.

3. Rushing, J., Huang, C., Chen, D., and Chung, Y.C. 1999. Evaluation of a modified chitosan biopolymer for coagulation of colloidal particles. Journal of Environmental Sciences 147(6): 339-364.

4. Diaz, A., N. Rincon, A. Escorihuela, N. Fernandez, E. Chacin and C. F. Forster. 1999. A preliminary evaluation of turbidity removal by natural coagulants to Venezuela. Process Biochemistry 35(8): 391-395.

5. Al-Samawi, A. A. and E. M. Shokralla. 2006. An investigation into an indigenous natural coagulant. Journal of Environmental Science and Health 31(8): 1881-1897.

6. Motevaselian, M. 1980. Measurement of oak seed as medicine and nutrient. PhD. Thesis, University of Tehran, Tehran.

7. Torkaman, J., A. Mirshokrayi and H. Resalati. 2002 Bark extractives analysis of five Iranian hard wood species. Iranian Journal of Natural Resources 55(3): 397-405.

8. Ozacar, M. and A. Sengil. 2002. The use of tannins from Turkish Acorns in water treatment as a coagulant and coagulant aid. Turkish Journal of Engineering and Environmental Sciences 15(26):255-263.

9. Azimi, A., B. Valizadeh, M. R. Masoodinejad and A. Safarzadeh. 2007 Evaluation of Oak seed extracts in Chrome removal from leathering industry wastewater. International Journal of Environmental Studies 41(6): 5-10.

10. Zhou, Y., X. H. Xing, Z. H. Liu and C. Liwen. 2008. Enhanced coagulation of ferric chloride aided by tannic acid for phosphorous removal from wastewater. Chemosphere 72(2): 290-298.

11. Sciban, M., M. Klasnja, M. Antov and B. Skrbic. 2008. Removal of water turbidity by natural coagulants obtained from chestnut and acorn. Bioresource Technology 100(7): 6639-6643.

12. Roy, R. K. 2010. Design of Experiments Using the Taguchi Approach, John Wiley and Sons, NY. 


\title{
Evaluation of Tannic Acid as Coagulant for Water Turbidity Reduction in Preliminary Water Treatment
}

\author{
H. Hashemi nejad*, A. Taebi and P. Paydari'
}

(Received: September 30-2014 ; Accepted: January 9-2018)

\begin{abstract}
The goal of this study was to evaluate tannic acid as a coagulant in turbidity removal. Tests were designed using Taguchi method and carried out on the synthetic and natural turbid samples. In order to optimize turbidity removal by tannic acid, seven factors including $\mathrm{pH}$, coagulant dosage, rapid mixing rate, slow mixing rate, slow mixing time, sedimentation time and initial turbidity were investigated. The results revealed that in optimum conditions, tannic acid could $n$ remove up to 71 percent of synthetic turbidity and 66 percent of natural turbidity; also, tannic acid showed more coagulation activity in the lower initial turbidities. ANOVA analysis showed that initial turbidity and slow mixing time were the most important parameters in the turbidity removal by tannic acid. In general, this study showed that tannic acid was capable of removing turbidity and could be used instead of common coagulants in the preliminary treatment.
\end{abstract}

Keywords: Coagulation, Tannic acid, Jar test, Taguchi

1. Department of Water and Environment, College of Civil Engineering, Isfahan University of Technology, Isfahan, Iran.

*: Corresponding Author, Email: hhasheminejad@cc.iut.ac.ir 